during human calcitonin administration (Woodhouse et al., 1971 ; Bordier et al., 1972) the latter is possible and could lead to a reduction in deformity. Whether or not the bone fragility can be reduced depends on its cause. If as previously suggested the disease process is a variant of fragilitas ossium (Eyring and Eisenberg, 1968) then a favourable result is unlikely. If, however, the fragility is due simply to the formation of structurally abnormal bone as in adult Paget's disease (Schmorl, 1932; Bordier et al., 1972) successful treatment should prevent further fractures.

The histological findings in this case were similar to the other children previously reported (Eyring and Eisenberg, 1968; Thompson et al., 1969) and confirm the increased bone turnover; active osteoclasts and active osteoblasts were greatly increased in number. The changes in the present patient were indistinguishable from those found in active adult Paget's disease (Schmorl, 1932). It is interesting to note that a similar patient with severe radiological changes had a normal serum alkaline phosphatase level, although osteoclasts and osteoblasts were abundant in the bone biopsy specimen (Bakwin and Elger, 1956). Loss of bone mass assessed radiologically has sometimes been reported but this was not observed in the present patient. Reduced bone mass would result from a relative increase in bone resorption over bone formation, a situation likely to be made worse or initiated by the gross restriction in physical activity that is frequently seen, and also by the occasional reported use of steroid medication (Eyring and Eisenberg, 1968).

There are many striking similarities between adult Paget's disease and the high turnover bone disease described in children; serum alkaline and serum acid phosphatase levels are raised, urine hydroxyproline excretion is increased, and a mosaic pattern is present in the bone biopsy samples. Because of this, and to simplify matters, we used the eponym "Paget's" disease to describe the present patient, although we are fully aware that there is no proof linking the two diseases processes.

We wish to thank Dr. A. Glen and Mr. A. McDougal, of the Victoria Infirmary, Glasgow, for kindly allowing us to study a patient under their care, Dr. H. Hobitz and Professor M. Staehelin, of Ciba-Geigy Limited, for support and supplies of human calcitonin, and Sister K. Boon and Miss E. Priestly for skilled help with the balance. This work was in part supported by the Welloome Trust and the Medical Research Council (I. MacI.).
Correspondence should be addressed to: Dr. G. F. Joplin, Royal Postgraduate Medical School, Ducane Road, London W12 0HS.

\section{Addendum}

After three months' treatment a further reduction in bone turnover occurred. Serum alkaline phosphatase fell from 187 to 95 K.A.U., and urine hydroxyproline fell from 687 to $327 \mathrm{mg} \mathrm{a}$ day. In spite of several hard falls no further fractures occurred. Occasional mild nausea was the only reported side effect of the injections.

\section{References}

Bakwin, H., Elger, M. S. (1956). Fournal of Pediatrics, 49, 558.

Bordier, Ph., Woodhouse, N. J. Y., Joplin, G. F., and MacIntyre, I. (1972). fournal of Bone and foint Surgery. In press.

Caffey, J. (1961). Pediatric X-ray Diagnosis, 4th edn., p. 1042. Chicago, Year Book Medical Publishers.

Choremis, C., Yannakos, D., Papadatos, C., and Baroutsou, E. (1958). Helvetica Paediatrica Acta, 13, 185.

Dunnigan, M. G., and Gardner, M. D. (1965). Scottish Medical fournal, 10,325 . Eyring, E. J., and Eisenberg, E. (1968). Fournal of Bone and foint Surgery,

Facon, I. G., Moreira, G., Uehlinger, E., and Giedion, A. (1964). Helviteca Paediatrica Acta, 19, 279.

Fisher, M. T., Atkins, P. A., and Joplin, G. F. (1972). Clinica Chimica Acta,

In press.
Galante, L., Colston, K. W., Macauley, S. J., and MacIntyre, I. (1972).

Nature, In press.
Hartford, W. H. (1953). Analytical Biochemistry, 25, 290.

Kivirikko, K. I., Laitinen, O., and Prockop, D. J. (1967). Analytical Biochemistry, $19,249$.

MacIntyre, $\mathbf{1}$. (1960). Advances in Clinical Chemistry, 4, 1.

Marshall, W. C., and Moncrieff, A. A. (1962). Proceedings of the Royal Society of Medicine, 55, 238.

Pappas, A. M., Miller, M. E., Anderson, M., and Green, W. T. (1971). Clinical Orthopaedics and Related Research, 74, 241.

Schmorl, G. (1932). Virchows Archiv für pathologische Anatomie und Physiologie und für klinische Medizin, 283, 694.

Sieber, P., Riniker, B., Brugger, M., Kamber, B., and Rittel, W. (1970). Helvetica Chimica Acta, 53, 2135.

Stimmerman, G. N. (1966). American fournal of Pathology, 48, 641.

Swoboda, J. W. (1958). Helvetica Paediatrica Acta, 13, 292.

Thalassinos, N. C., Leese, B., Latham, S. C., and Joplin, G. F. (1970). Archives of Disease in Childhood 45, S. C.

Thompson, R. C., Gaull, G. E., Horwitz, S. J., and Schenk, R. K. (1969). American fournal of Medicine, 47, 209.

Whitby, L. G., and Lang, D. (1960). Fournal of Clinical Investigation, 39, 854. Woodhouse, N. J. Y., et al. (1971). Lancet, 2, 1139.

Wootton, I. D. P. (editor) (1964). Microanalysis in Medical Biochemistry, New York, Grune and Stratton.

\title{
Pulmonary Aspiration after Fibre-endoscopy of the Upper Gastrointestinal Tract
}

\author{
B. J. PROUT, C. METREWELI
}

British Medical fournal, 1972, 4, 269-271

\section{Summary}

Pulmonary aspiration occurred in 16 out of 65 patients (24.6\%) undergoing fibre-endoscopic examinations of the upper gastrointestinal tract under intravenous sedation, but it was rarely followed by serious complications. Aspiration was found to occur under sedation with diazepam alone, diazepam with atropine, and with chlormethiazole. The most important factors contributing to aspiration are the local pharyngeal

Royal Cornwall Hospital, Truro, Cornwall

B. J. PROUT, M.D., M.R.C.P., Consultant Physician

C. METREWELI, M.B., B.CHIR., Registrar anaesthesia and the mechanical interference of the fibrescope with laryngeal closure and swallowing. The patient is also at risk of aspiration after completion of the procedure and should remain recumbent until the local anaesthesia has worn off.

\section{Introduction}

Fibre-endoscopic examination of the gastrointestinal tract under intravenous sedation is now widely practised. We have been concerned with the possible danger of aspiration into the lungs during this procedure, and we have looked at the potential factors involved in increasing the risk. These are the nature of the sedative agent, the dose of the agent used, local oropharyngeal anaesthesia, and the use of antisialogogues. 


\section{Methods}

Patients selected for gastroscopy had haemoglobin, prothrombin time, and platelet count checked, and usually had a barium-meal and chest $x$-ray examination beforehand. Details of the investigation were explained to them and their consent obtained. A history of allergy to iodine was sought, as this contra-indicated the subsequent use of Lipiodol (iodised oil viscous injection) in this study. Each patient was fasted for a minimum of four hours. In the hour before examination oropharyngeal and oesophageal anaesthesia was achieved by dissolving a benzocaine lozenge $(100 \mathrm{mg})$ in the mouth and repeating at 30 minutes. When the patient was on
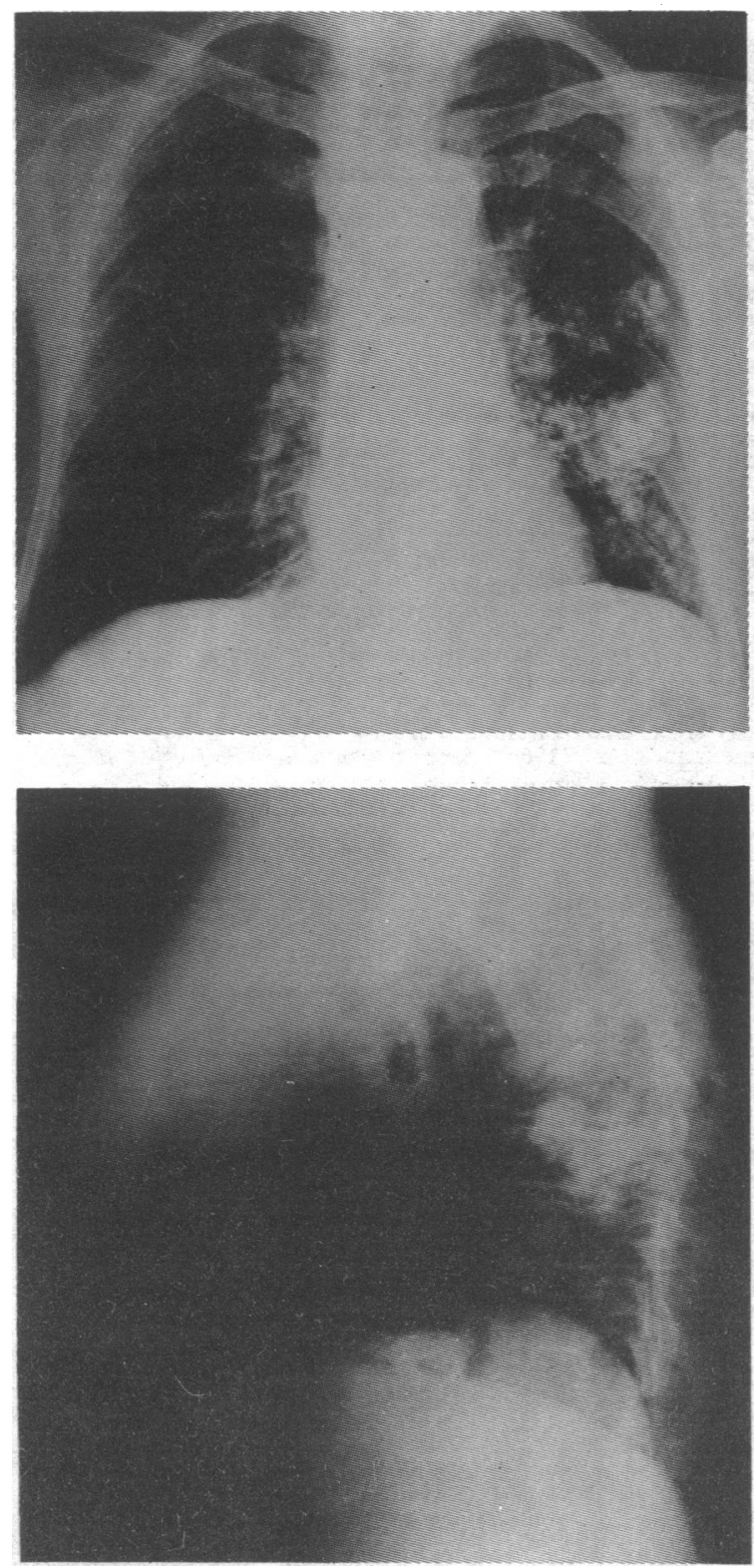

$X$-ray films showing extensive aspiration of Lipiodol into the left lung (postenor-anterior and left lateral).

the examination couch further local anaesthesia was obtained by spraying the back of the throat with an orange-flavoured Xylocaine spray (lignocaine hydrochloride).

The patients were divided into three groups according to the sedative regimen. One group received diazepam alone, a second group received chlormethiazole, and a third group received diazepam with atropine. The sedative agent was administered by slow intravenous injection of increments of the agent until the patient was adequately sedated, as judged by the appearance of drowsiness, dysarthria, ptosis, hiccups, and nystagmus. The dose of diazepam required to reach this stage of sedation varied between 5 and $100 \mathrm{mg}$. The dose of chlormethiazole used varied between 300 and $2,480 \mathrm{mg}$. This variation of dosage of the sedative agent used and its relation to gastrointestinal fibroptic examination has been discussed in detail elsewhere (Metreweli and Prout, 1972).

The patients were examined lying in the left lateral position, and the Olympus G.I.F.D. oesophagogastrofibrescope or Olympus G.F.B. gastrofibrescope were introduced in the standard manner. Patients frequently coughed and gagged during this procedure but soon settled for the remainder of the examination. The examination period was 30-40 minutes.

Ten to 15 minutes after introduction of the fibrescope, and with the instrument held steady in position, $5 \mathrm{ml}$ of Lipiodol Ultra-Fluid (iodised oil fluid injection) were introduced into the mouth by slow injection from a disposable syringe via a large-bore blunt plastic cannula (Luer filler needle, Pharmax Ltd.). The patient was requested to swallow this fluid as it was introduced. The end of the plastic cannula was placed on the tongue, projecting not more than $2 \mathrm{~cm}$ into the buccal cavity. This process was repeated between 30 and 40 minutes after intubation with the fibrescope still in situ.

At the end of the examination the patients were capable of rising from the couch and being taken by wheel chair to the radiographic department for a posterior-anterior and lateral chest film. The presence of chest symptoms or signs were sought the day after examination if the patient was an inpatient or at the subsequent visit in the case of outpatients. The results are summarized in the Table.

Frequency of Aspiration in Each Drug Group

\begin{tabular}{l|c|c|c|c}
\hline Drug Group & $\begin{array}{c}\text { Total No. } \\
\text { of Patients }\end{array}$ & $\begin{array}{c}\text { Total No. } \\
\text { of Aspirations }\end{array}$ & $\begin{array}{c}\text { Aspiration } \\
\text { during } \\
\text { Eramination }\end{array}$ & $\begin{array}{c}\text { Aspiration after } \\
\text { Eramingtion } \\
\text { (sec text) }\end{array}$ \\
\hline $\begin{array}{l}\text { Diazepam . } \\
\text { Chlormethiazole } \\
\text { Diazepam + } \\
\text { atropine }\end{array}$ & 31 & 9 & 5 & 4 \\
\hline Total .. & 17 & 4 & 2 & 1 \\
\hline
\end{tabular}

\section{Discussion}

The results show that a surprising number of patients, 16 out of $65(24.6 \%)$, aspirated small quantities of iodised oil during these examinations. Occasionally aspiration occurred into larger areas of lung (see Fig.). This implies that a similar number of patients aspirate small quantities of saliva and possibly some gastric juice during the examination.

None of the patients in this series, or inded other patients under our care not included in this study, have so far developed unpleasant pulmonary sequelae, but these have been reported in a large combined series by Taylor, Cotton, Towey, and Gent (1972). Despite the small number of cases studied in this series it is none the less clear that this is not a specific effect of the sedative agent alone, as aspiration occurred in all three sedative groups.

Healy and Vickers (1971) concluded that for a period of five to 10 minutes after diazepam injection the patients undergoing dental treatment were able to aspirate foreign material into the trachea during the act of swallowing, but this was presumed to be as a result of impairment of the glottic closure reflex. None of their patients challenged at 10 minutes and later after diazepam injection showed evidence of aspiration. All of the present patients were, however, challenged 10 minutes after injection of diazepam-that is, in the period regarded as safe.

Diazepam encourages salivation (Dundee and Haslett, 1970), which might be a contributory factor towards aspiration, but the use of atropine as an antisialogogue did not protect against this hazard despite the fact that all patients in whom atropine 
was used were noticeably drier. The quantity of intravenous sedative used does not appear to be significant, as those patients that aspirated had not had unusually high doses.

When we reviewed the radiographs of those patients who had aspirated, five out of $16(31.3 \%)$ had evidence of aspiration into the right lower zone. It would be unlikely that aspiration would occur into this site while lying on the left side, and we therefore concluded that the patients had aspirated when sitting upright after the examination. Aspiration presumably occurred some 40 minutes after initial sedation. At this time the action of the sedatives is diminished but local anaesthesia is still prominent. Efficient oropharyngeal anaesthesia, however, is an essential prerequisite of gastrointestinal fibre-endoscopic examination. Consequently we no longer allow patients to sit up after examination. They are instructed to stay horizontal until pharyngeal anaesthesia is no longer present.

Another factor contributing to the risk of aspiration is the mechanical interference with glottic closure and swallowing caused by the presence of the fibrescope. This and the effect of local anaesthesia are unavoidable.

We do not think that the nature of the intravenous sedative used is of prime importance as has been suggested elsewhere (Taylor et al., 1972) but is due to the unavoidable features inherent in this particular type of examination. We wish to draw attention to the fact that aspiration occurs more commonly than may have been suspected, although rarely followed by serious complications. None occurred in the present series. We therefore suggest that clinicians referring patients for endoscopy should be aware of the risk of pulmonary aspiration complicating the investigation.

We wish to thank Sister M. M. Symons and Mrs. B. Jewell for their help with the examinations, and Miss F. Hocking for typing the manuscript.

\section{References}

Dundee, J. W., and Haslett, W. H. K. (1970). British fournal of Anaesthesia, 42, 217.

Healey, T. E. J and Vickers, M.D. (1971). Proceedings of the Royal Society of Medicine, 64, 85.

Metreweli, C., and Prout, B. J. (1972). In press. British Medical Fournal, 1, 666.

\title{
Rubella Vaccination and Termination of Pregnancy
}

\author{
HÉLENE J. MAIR, ALAN R. BUCHAN
}

British Medical fournal, 1972, 4, 271-273

\section{Summary}

Six terminations of pregnancy have been carried out in Leicestershire since February 1970 because of rubella vaccine administered inadvertently during early unrecognized pregnancy. Any woman of child bearing age shown by serological tests to be susceptible to rubella should be offered vaccination, preceded and followed by adequate contraception.

\section{Introduction}

Circular 17/72 from the Department of Health and Social Security (1972) advises against routine rubella vaccination of women of childbearing age but recommends immunization for women in this age group who request protection, for women in the postpartum period, and for women at special risk of acquiring or transmitting rubella, provided in all cases that they are seronegative and are fully aware of the need to avoid pregnancy for at least two months after receiving the vaccine.

Public Health Laboratory, Leicester

HÉLÈNE J. MAIR, M.D., M.R.C.PATH., Consultant Virologist

County Health Department, Leicestershire

ALAN R. BUCHAN, M.D., D.P.H., County Medical Officer
Vaccination programmes are still in the early stages, but already experience in Leicestershire indicates that the safe administration of rubella vaccine is not as simple as might appear at first sight.

\section{Preliminary Findings}

Termination of pregnancy after rubella vaccination was considered necessary on six occasions in which the Public Health Laboratory in Leicester was involved between February 1970 and May 1972 (see Table). Three of the terminations (Cases 4, 5, and 6) were performed within 14 weeks in 1972 . With the exception of the pregnancy of a 16-year-old unmarried girl (Case 2), all were "wanted" babies. Cases 1 and 3 were known to be seronegative before vaccination, and both women had been advised not to become pregnant for at least eight weeks. One started menstruation the day after vaccination but conceived within the next 14 days. Arrangements were made for termination at 11 weeks but spontaneous abortion occurred a week earlier. The products of conception did not contain rubella virus (MacDonald et al., 1971).

Rubella vaccine was given to the remaining four women without previous estimation of their immune state. At least one woman is known not to have received any warning of the risks of pregnancy when immunized by a relief surgery nurse. In the case of the unmarried girl her doctor judged the risk of pregnancy to be negligible and advice therefore unnecessary. In four

Details of Patients inoculated with Rubella Vaccine during Pregnancy

\begin{tabular}{|c|c|c|c|c|c|c|}
\hline Case No. & Age & $\begin{array}{c}\text { Prevaccination } \\
\text { Haemagglutination } \\
\text { Inhibition Test }\end{array}$ & Last Menstrual Period & Date of Vaccination & $\begin{array}{l}\text { Postvaccination } \\
\text { Haemagglutination } \\
\text { Inhibition Test }\end{array}$ & Termination \\
\hline $\begin{array}{l}1 \\
2 \\
3\end{array}$ & $\begin{array}{l}23 \\
16 \\
20\end{array}$ & \multirow[t]{2}{*}{$\begin{array}{c}5 \text { December } 1969,<8 \\
23 \text { March } 1971,<8 \\
6 \text { April } 1971,<8\end{array}$} & $\begin{array}{l}16 \text { December } 1969 \\
12 \text { October } 1970 \\
15 \text { April } 1971\end{array}$ & $\begin{array}{l}15 \text { December } 1969 \\
2 \text { November } 1970 \\
22 \text { April } 1971\end{array}$ & $\begin{array}{c}27 \text { January } 1970,+80 \\
11 \text { March } 1971,+128 \\
26 \text { June } 1971,+256\end{array}$ & $\begin{array}{c}28 \text { February } 1970 \\
11 \text { March } 1971 \\
7 \text { July } 1971\end{array}$ \\
\hline $\begin{array}{l}4 \\
5 \\
6\end{array}$ & $\begin{array}{l}25 \\
25 \\
27\end{array}$ & & $\begin{array}{l}13 \text { November } 1971 \\
11 \text { February } 1972 \\
18 \text { February } 1972\end{array}$ & $\begin{array}{c}19 \text { November } 1971 \\
19 \text { February } 1972 \\
8 \text { March } 1972\end{array}$ & $\begin{array}{c}28 \text { January } 1972,+32 \\
28 \text { April 1972, }+64\end{array}$ & $\begin{array}{l}7 \text { February } 1972 \\
26 \text { April } 1972 \\
11 \text { May } 1972\end{array}$ \\
\hline
\end{tabular}

